石油技術拹會誌 第 22 卷第 5 號（昭和 32 年 9 月）

JOURNAL OF THE JAPANESE ASSOCIATION OF PETROLEUM TECHNOLOGISTS

VOL. 22, NO. 5 (Sept., 1957)

\title{
泥水の化学的処理飞関する基礎的研究 (II)
}

藤 井 清 光*

(昭和 32 年 9 月 10 日受理)

Study on the Chemical Treatment of Dilling Fluids, Part 2

By

Kiyomitsu FUJII

\section{VIII. 泥水に対する $\mathrm{Ca}(\mathrm{OH})_{2}$ の作用}

ベントナイト泥水に対す名水酸化カルシウム $\mathrm{Ca}(\mathrm{OH})_{2}$ の作用は、第16表より知ることができる。すなわちごく 僅かの水酸化カルシウムの混合心より, 泥水の性質は非 宵に悪くなる。とのことは特に温度が高くなると著し 心。温度に関する実験は泥水定 $150^{\circ} \mathrm{C} て ゙ 5$ 洔間保吉, 泠 えてからその性質齐測定したものである。

次汇第17表は,あらかじめCM C**が混合されたベン トナイト泥水に対する水酸化カルシウムの作用走示す。 元のベントナイト泥水の比重は 1.025 , 粘性（分散状 態） 6.1 c.p. である。との表の上部には，比較のた め, 水酸化カルシウムの混合さ沉ない泥水の性質が示し てある。おの抢のの泥水には粘性降下剂が $1 \% ， 2 \%$ 扮 よび $5 \%$ 加えられた(比較のため), 同じ量の水学加えた泥

第 16 表 $\mathrm{Ca}(\mathrm{OH})_{2}$ の作用*

\begin{tabular}{|c|c|c|c|c|c|c|}
\hline \multirow{2}{*}{$\begin{array}{c}\mathrm{Ca} \\
(\mathrm{OH})_{2} \\
\%\end{array}$} & \multirow{2}{*}{$\mid \begin{array}{l}\text { 粘性** } \\
\text { c.p. }\end{array}$} & 湽 & 過 試 & 験 & $\begin{array}{l}\text { 測定 } \\
\text { 温度 }\end{array}$ & \multirow{2}{*}{ 泥水の状態 } \\
\hline & & $\begin{array}{l}1 \text { 分 } \\
\mathrm{cc}\end{array}$ & $\begin{array}{c}30 \text { 分 } \\
\mathrm{cc}\end{array}$ & $\begin{array}{l}\text { 㫛壁 } \\
\mathrm{mm}\end{array}$ & ${ }^{\circ} \mathrm{C}$ & \\
\hline - & 24 & 4.0 & 21.5 & 2 & 20 & \multirow{3}{*}{ 普通の状態 } \\
\hline 0.2 & 1100 & 8.5 & 51.0 & 3 & 25 & \\
\hline 1.0 & 1400 & 23.5 & 112.0 & 20 & 20 & \\
\hline 一 & 24 & 4.5 & 22.0 & 3 & 23 & $\begin{array}{l}150^{\circ} \mathrm{C} \text { にて } \\
5 \text { 時間保ち }\end{array}$ \\
\hline 0.2 & 27 & 16.0 & 83.0 & 7 & " & 冷えてから \\
\hline 1.0 & 2000 & 31.0 & 199.0 & 19 & " & 測定す \\
\hline \multicolumn{7}{|c|}{$\begin{array}{l}\text { * 元の泥水はベントナイト } 10 \mathrm{~g} \text { を水 } 100 \mathrm{cc} \text { に加えた } \\
\text { 8の } \\
\text { ** 分散状態 }\end{array}$} \\
\hline
\end{tabular}

* 東大助教授

** 日本 $\mathrm{CMC}$ 全社の製品
水の性質も测定してある。5％加えら礼た泥水社，その ま>静止状態に保たれ，24封間後に再で粘性(分散状態) が測定された。とれは静止状態において反応が進就が らか，確かめるためである。粘性降下剤としてはフミン 酸*** の溶液 $(\mathrm{NaOH} の 1 \%$ 溶液 $100 \mathrm{cc}$ にフミン酸 10 $\mathrm{g}$ 劣溶かしたもの)，タンニンの $0.3 \%$ およ゙ $1 \%$ 溶

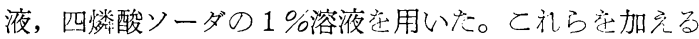
前の泥水の粘性には差があるので，粘性降下剂の作用考 比較するには粘性降下率，すなわち降下剂を加える前の 粘性に対する $5 \%$ 加えら沉た液の粘性の百分率学見る必 要がある。滤過試験は24時間後の粘性が測定された後に 行わ礼る。

$\mathrm{CMC}$ が $0.3 \%$ 混合された泥水に対する水酸化カルシ ウムの影響は，その混合量が $0.2 \%$ 時には，それ原ざ 大さくない。との混合量では, 滤過水が僅が増加し, 24 時間後の水の分離は僅かである。これに対しては, フミ ン酸が弱い改善作用をするだけで，他の薬品は無力であ る。水酸化カルシウムの混合量が $1 \%$ になると, 泥水注 非常に悪くなる。すなわち滤過水が極端に増加する。す ベとの粘性降下剂は, この亜い性質学改善するのに全く 無力である。

第18表は偱環試験の結果を示す。この泥水は他の泥水 に較バ，ごく僅かな水酸化カルシウムの混合であるにも かつわらず，その粘性が非常に不規則に変化するここが 特色である。すなわち泥水の性質が非常に不安定である とと京示している。

\section{IX. 泥水に対する NaOH の作用}

ベントナイト泥水に対する菇性ソーダ $\mathrm{NaOH}$ の作用 は第19表より知ることができる。との奏験は第17表の実

*** 帝国テルナイト工柴会社の製品 
第17表 $\mathrm{Ca}(\mathrm{OH})_{2}$ の作用 (温度 $25^{\circ} \mathrm{C}$ )

\begin{tabular}{|c|c|c|c|c|c|c|c|c|c|c|c|c|c|c|}
\hline \multicolumn{2}{|c|}{ 混合藥品 } & \multirow{2}{*}{$\begin{array}{l}\text { 粘性 降下荗 } \\
\text { の 種 類 }\end{array}$} & \multicolumn{5}{|c|}{ 粘性降下刘の混合による粘性* } & \multirow{2}{*}{\multicolumn{2}{|c|}{\begin{tabular}{|c|c|}
24 時間 & 24 時間 \\
後の粘 & 後の水 \\
c.p. & の分離 \\
c.p. & $\%$
\end{tabular}}} & \multirow{2}{*}{$\begin{array}{c}\text { 瘜 } \\
1 \text { 分 } \\
\text { cc }\end{array}$} & \multicolumn{2}{|c|}{ 過 試 験 } & \multicolumn{2}{|c|}{ アルカリ度 } \\
\hline $\begin{array}{c}\mathrm{Ca} \\
\mathrm{OH})_{2}\end{array}$ & CMC & & $\begin{array}{l}0 \% \\
\text { c.p. }\end{array}$ & $\begin{array}{l}1 \% \\
\text { c.p. }\end{array}$ & $\begin{array}{l}2 \% \\
\text { c.p. }\end{array}$ & $\begin{array}{l}5 \% \\
\text { c.p. }\end{array}$ & $\begin{array}{c}\text { 降下率 } \\
\%\end{array}$ & & & & $\begin{array}{c}30 \text { 分 } \\
\mathrm{cc}\end{array}$ & $\begin{array}{l}\text { 泥壁 } \\
\mathrm{mm}\end{array}$ & $\begin{array}{l}\mathrm{P} \\
\mathrm{cc}\end{array}$ & $\begin{array}{l}\mathrm{M} \\
\mathrm{cc}\end{array}$ \\
\hline - & - & - & - & - & - & - & - & - & 0 & 3.5 & 20.0 & 0.5 & - & - \\
\hline - & 0.3 & 水 & 500 & 380 & 340 & 300 & 60 & 270 & 0 & 3.5 & 13.5 & 0.5 & - & - \\
\hline - & " & フミン酸溶液 & 380 & 310 & 290 & 280 & 74 & 73 & 0 & 3.0 & 13.5 & 0.5 & - & - \\
\hline - & " & $\begin{array}{l}\text { タンニン } 0.3 \\
\text { \%済液 }\end{array}$ & 390 & 290 & 230 & 200 & 51 & 42 & 0 & 2.5 & 12.5 & 0.5 & 一 & - \\
\hline - & " & $\begin{array}{l}\text { タンニン } 1 \% \\
\text { 溶液 }\end{array}$ & 350 & 240 & 220 & 200 & 57 & 180 & 0 & 2.5 & 12.5 & 0.5 & - & - \\
\hline 一 & " & $\begin{array}{l}\text { 四燐酸ソーダ } \\
1 \% \text { 溶液 }\end{array}$ & 510 & 310 & 240 & 180 & 35 & 170 & 0 & 1.0 & 11.5 & 0.5 & - & - \\
\hline 0.2 & 0.3 & 水 & 110 & 69 & 61 & 68 & 62 & 18 & 2 & 3.0 & 15.5 & 0.5 & 0.6 & 1.4 \\
\hline " & " & フミン酸溶液 & 150 & 97 & 90 & 82 & 54 & 44 & 0 & 2.5 & 12.5 & 0.5 & - & - \\
\hline " & " & $\begin{array}{l}\text { タンシ二ン } 0.3 \\
\text { \%溶液 }\end{array}$ & 180 & 150 & 120 & 69 & 38 & 36 & 3 & 4.5 & 16.5 & 0.5 & 0.5 & 0.9 \\
\hline " & $"$ & $\begin{array}{l}\text { 四燐酸ソーダ } \\
1 \% \text { 溶液 }\end{array}$ & 110 & 84 & 69 & 56 & 51 & 29 & 3 & 4.0 & 15.5 & 0.5 & - & - \\
\hline 1.0 & 0.3 & 水 & 370 & - & - & 470 & 126 & 770 & 7 & 30.0 & 150.0 & 15.0 & 2.2 & 2.8 \\
\hline$"$ & " & フミン酸溶液 & 370 & - & - & 380 & 102 & 240 & 7 & 16.5 & 84.0 & 15.0 & - & 1 \\
\hline$"$ & " & $\begin{array}{l}\text { タンニン } 0.3 \\
\text { \%溶液 }\end{array}$ & 370 & - & - & 300 & 81 & 610 & 7 & 20.5 & 132.0 & 14.0 & 2.3 & 2.8 \\
\hline " & " & $\begin{array}{l}\text { 四燐酸ソーダ } \\
1 \% \text { 溶液 }\end{array}$ & 370 & - & - & 390 & 105 & 570 & 7 & 25.0 & 120.0 & 11.0 & 2.4 & 3.0 \\
\hline
\end{tabular}

* 分散状態

第18表 $\mathrm{Ca}(\mathrm{OH})_{2}$ 混合泥水の循環試験*

\begin{tabular}{|c|c|c|}
\hline 経 過 時 間 & 粘性 c. p. & 温 ${ }^{\circ}$ 度 ${ }^{\circ}$ \\
\hline 0 & 310 & 29 \\
0.5 & 2730 & 29 \\
1.5 & 910 & 30 \\
4.0 & 950 & 31 \\
\hline 17 時間静置後 & 1320 & 26 \\
0 & $(51)$ & 11 \\
0.5 & 520 & 34 \\
2.0 & 490 & 38 \\
\hline
\end{tabular}

* ベントナイト $10 \mathrm{~g} / 100 \mathrm{cc}$ 液に対し $\mathrm{Ca}(\mathrm{OH})_{2} 0,1 \%$ 溶液と $5 \%$ 加 えたもの。粘性は結合状態，たぶし（）は分散状態。

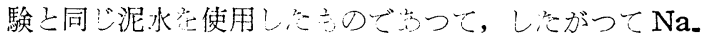
$\mathrm{OH}$ 方混会き!次心泥水の性質は, 第17表の上部示さ

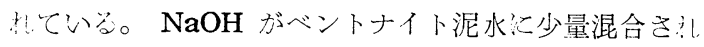
ると，粘性が上る。粘性降下剂は，この上つた粘性㱏か

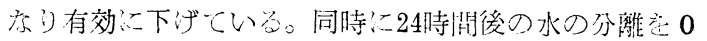
にしている。 $\mathrm{NaOH}$ の混合留が多くなる上, 泥水の粘

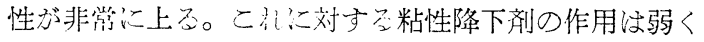

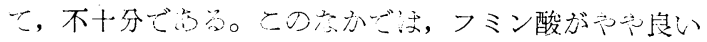

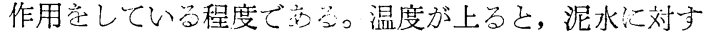

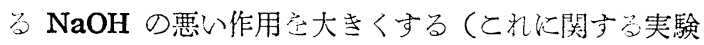
結果は，表化示さ沉いか心。

$\mathrm{NaOH}$ が混合さ沉泥水の循環試験以第 20 表江示し こ㐫る。との表でわ示学引う，との泥水の粘性の変化

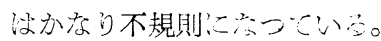

\section{X. 泥水に対する $\mathrm{Ca}(\mathrm{OH})_{2}$ および $\mathrm{NaOH}$ の作用}

ベントナイト泥水に $\mathrm{Ca}(\mathrm{OH})_{2}$ 招よび $\mathrm{NaOH}$ 混合

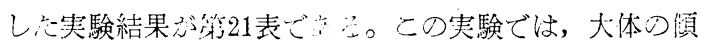

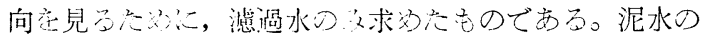

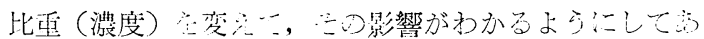

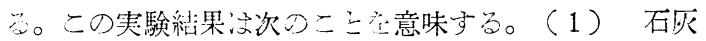

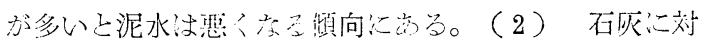

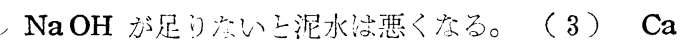

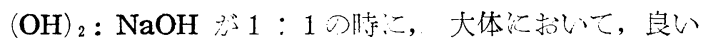

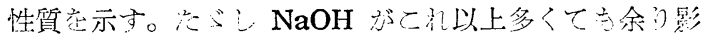

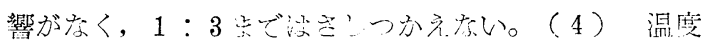

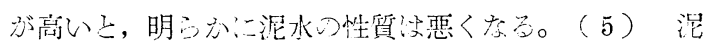


第 19 表 $\mathrm{NaOH}$ の作用 (温度 $26^{\circ} \mathrm{C}$ )

\begin{tabular}{|c|c|c|c|c|c|c|c|c|c|c|c|c|c|c|}
\hline \multicolumn{2}{|c|}{ 混合薬品 } & \multirow{2}{*}{$\begin{array}{l}\text { 粘 性 降下刘 } \\
\text { の 種 類 }\end{array}$} & \multicolumn{5}{|c|}{ 粘性降下刘の混合による粘性* } & \multirow{2}{*}{\multicolumn{2}{|c|}{\begin{tabular}{|c|c|}
24 時間 & 24 時間 \\
後の粘 & 後の水 \\
性 & の分離 \\
c.p. & $\%$
\end{tabular}}} & \multirow{2}{*}{$\frac{\text { 濾 }}{1 \text { 分 }}$} & \multicolumn{2}{|c|}{ 過 試 歌 } & \multicolumn{2}{|c|}{ アルカワ度 } \\
\hline$\underset{\%}{\mathrm{NaOH}}$ & $\underset{\%}{\mathrm{CMC}}$ & & $\begin{array}{l}0 \% \\
\text { c.p. }\end{array}$ & $\begin{array}{l}1 \% \\
\text { c.p. }\end{array}$ & $\begin{array}{l}2 \% \\
\text { c.p. }\end{array}$ & $\begin{array}{l}5 \% \\
\text { c.p. }\end{array}$ & $\begin{array}{c}\text { 降下率 } \\
\%\end{array}$ & & & & $\begin{array}{c}30 \text { 分 } \\
\mathrm{cc}\end{array}$ & $\begin{array}{l}\text { 泥壁 } \\
\mathrm{mm}\end{array}$ & $\begin{array}{l}P \\
c c\end{array}$ & $\begin{array}{l}\mathrm{M} \\
\mathrm{cc}\end{array}$ \\
\hline 0.2 & 0.3 & 水 & 1300 & 1200 & 980 & 810 & 62 & 330 & 2 & 1.5 & 10.0 & 0.5 & 1.2 & 2.1 \\
\hline " & " & フミン酸溶液 & 1700 & 670 & - & 130 & 8 & 81 & 0 & 3.0 & 12.5 & 0.5 & - & - \\
\hline " & " & $\begin{array}{l}\text { タンニン } 0.3 \\
\text { \%溶液 }\end{array}$ & 1500 & 850 & 480 & 190 & 13 & 150 & 0 & 2.5 & 12.0 & 0.5 & 1.1 & 2.0 \\
\hline$"$ & " & $\begin{array}{l}\text { 四燐酸ソーダ } \\
1 \% \text { 溶液 }\end{array}$ & 1500 & 790 & 330 & 200 & 13 & 170 & 0 & 2.5 & 10.5 & 0.5 & 一 & - \\
\hline 1.0 & 0.3 & 水 & 3400 & - & - & 2400 & 71 & 510 & 3 & 2.3 & 13.0 & 1.5 & 8.5 & 10.8 \\
\hline " & " & フミン酸溶液 & 3400 & - & - & 450 & 13 & 220 & 0 & 4.5 & 13.5 & 1.0 & - & - \\
\hline " & " & $\begin{array}{l}\text { タンニン } 0.3 \\
\text { \%溶液 }\end{array}$ & 3400 & - & - & 1900 & 56 & 550 & 2 & 4.0 & 14.5 & 1.0 & 8.0 & 9.4 \\
\hline$"$ & " & $\begin{array}{l}\text { タンニン } 1 \% \\
\text { 溶液 }\end{array}$ & 3400 & - & - & 960 & 30 & 340 & 2 & 3.0 & 12.5 & 1.0 & - & 一 \\
\hline " & " & $\begin{array}{l}\text { 四燐酸ソーダ } \\
1 \% \text { 液 }\end{array}$ & 3400 & - & - & 1900 & 56 & 610 & 1 & 7.0 & 17.0 & 1.0 & 9.5 & 10.7 \\
\hline
\end{tabular}

* 分散状態

第20表 $\mathrm{NaOH}$ 混合泥水の循環試験*

\begin{tabular}{|c|c|c|c|c|}
\hline $\mathrm{NaOH}$ 溶液濃度\% & \multicolumn{2}{|c|}{0.1} & \multicolumn{2}{|c|}{1.0} \\
\hline 経 過 時 間 & $\begin{array}{c}\text { 粘性 } \\
\text { c.p. }\end{array}$ & $\begin{array}{c}\text { 温度 } \\
{ }^{\circ} \mathrm{C}\end{array}$ & $\begin{array}{c}\text { 粘性 } \\
\text { c.p. }\end{array}$ & $\begin{array}{c}\text { 温度 } \\
{ }^{\circ} \mathrm{C}\end{array}$ \\
\hline 0 & 130 & 29 & 26 & 28 \\
0.5 & 78 & 29 & 47 & 28 \\
2.0 & 84 & 31 & 49 & 29 \\
4.5 & 110 & 32 & 53 & 25 \\
\hline 16.5 時間静置後 & 540 & 29 & 400 & 26 \\
0 & $(140)$ & $\prime \prime$ & $(28)$ & " \\
0.5 & 480 & 28 & 30 & 26 \\
3.0 & 390 & 28 & 26 & 27 \\
\hline
\end{tabular}

*ペントナイト $10 \mathrm{~g} / 100 \mathrm{cc}$ の液に対し $\mathrm{NaOH}$ 溶液を $5 \%$ 混含す。 粘性は結合状態，たぶし(）は分散状態を示す。

水の比重くなるを，滤渦水は少なくなる(たぶし粘 性湻くなる）。

ベントナイト泥水に $\mathrm{Ca}(\mathrm{OH})_{2}, \mathrm{NaOH}$ 捻よび溉粉在 混合した実験結果が符22表である(ベントナイトは第21 表の実験と同じちのである)。との実験結果は次のとと を意見する。（1）第21表の実験と輷べ，溉粉が 0.5 \%加わるととにより, 滤過水は少なくなる。澱粉が 1.5 \%加わるとさらに少なくなる。(2) 石灰に対し $\mathrm{NaOH}$ が少ないと泥水は恶くなる。（3） $\mathrm{Ca}(\mathrm{OH})_{2}$ と $\mathrm{NaOH}$

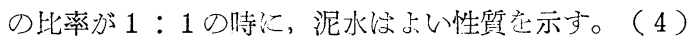
泥水の比重が高くなると, 滤過水沙少なくなる。（5） $30^{\circ} \mathrm{C}$ 以下の泥水の性質々 $60^{\circ} \mathrm{C}$ 性質と苦比較すると，滤 過水には余り変化がない（温度の影響に関する実験結果
第 21 表 $\mathrm{Ca}(\mathrm{OH})_{2}$ 扎よび $\mathrm{NaOH}$ の作用, 濾過水 (1～30分) の值

\begin{tabular}{|c|c|c|c|c|c|}
\hline \multirow{2}{*}{$\underset{\%}{\mathrm{Ca}(\mathrm{OH})_{2}}$} & \multirow{2}{*}{$\underset{\%}{\mathrm{NaOH}}$} & \multicolumn{3}{|c|}{ 泥水の比重 } & \multirow{2}{*}{$\begin{array}{l}\text { 温度 } \\
{ }^{\circ} \mathrm{C}\end{array}$} \\
\hline & & $\begin{array}{c}1.023 \\
\mathrm{cc}\end{array}$ & $\begin{array}{c}1.040 \\
\mathrm{cc}\end{array}$ & $\begin{array}{c}1.067 \\
\mathrm{cc}\end{array}$ & \\
\hline 0.1 & 0.1 & 19.5 & 12.4 & 10.5 & \multirow[t]{12}{*}{$23 \sim 28$} \\
\hline " & 0.3 & 22.0 & 15.0 & 11.0 & \\
\hline " & 0.5 & 28.0 & 18.5 & 12.5 & \\
\hline 0.3 & 0.1 & 35.5 & 16.5 & 12.5 & \\
\hline " & 0.3 & 29.0 & 18.0 & 13.5 & \\
\hline " & 0.5 & 27.3 & 19.0 & 14.0 & \\
\hline 0.5 & 0.1 & 69.0 & 22.0 & 20.0 & \\
\hline " & 0.3 & 36.0 & 22.5 & 16.0 & \\
\hline " & 0.5 & 38.5 & 21.5 & 14.8 & \\
\hline " & 1.0 & 26.5 & 20.5 & 14.6 & \\
\hline 1.0 & 0.5 & 28.0 & 22.0 & 一 & \\
\hline " & 1.0 & 26.0 & 21.0 & 一 & \\
\hline 0.1 & 0.3 & 一 & 28.0 & - & \multirow[t]{5}{*}{60} \\
\hline " & 0.5 & - & 25.0 & - & \\
\hline 0.3 & 0.3 & 33.5 & - & - & \\
\hline 0.5 & 0.1 & - & 86.0 & 一 & \\
\hline " & 0.3 & 50.0 & 42.5 & 一 & \\
\hline
\end{tabular}

注より除(て西る)。

以上で明ら就々う飞, $\mathrm{Ca}(\mathrm{OH})_{2}$ 拉よで $\mathrm{NaOH}$ が

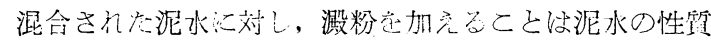
を改善する。

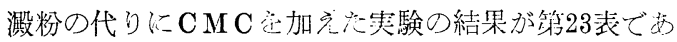
そ。との実験では水 $100 \mathrm{cc}$ そベントナイト $6 \mathrm{~g}$ の浱度の 
第 22 表 $\mathrm{Ca}(\mathrm{OH})_{2}, \mathrm{NaOH}$ 和よび溉粉の作用, 濾過水（1 30分）の值（温度 $23 \sim 28^{\circ} \mathrm{C}$ )

\begin{tabular}{|c|c|c|c|c|c|}
\hline \multirow{2}{*}{$\underset{\%}{\mathrm{Ca}(\mathrm{OH})_{2}}$} & \multirow{2}{*}{$\underset{\%}{\mathrm{NaOH}}$} & \multirow{2}{*}{ 溉 粉 } & \multicolumn{3}{|c|}{ 泥水の比重 } \\
\hline & & & $\begin{array}{c}1.033 \\
\text { cc }\end{array}$ & $\begin{array}{c}1.045 \\
\text { cc }\end{array}$ & $\begin{array}{c}1.062 \\
\mathrm{cc}\end{array}$ \\
\hline 0 & 0 & 0 & - & 15.0 & 8.0 \\
\hline 0.1 & 0.1 & 0.5 & 14.0 & 12.0 & - \\
\hline " & 0.5 & 0.5 & 11.0 & 10.4 & 7.6 \\
\hline " & " & 1.5 & 5.5 & 4.0 & 5.0 \\
\hline 0.5 & 0.1 & 0.5 & 59.0 & 54.5 & 39.0 \\
\hline " & " & 1.5 & 70.0 & 44.5 & 32.4 \\
\hline " & 0.3 & 0.5 & 32.0 & 22.0 & 19.0 \\
\hline " & " & 1.5 & 22.0 & 16.0 & 13.0 \\
\hline " & 0.5 & 0.5 & 11.0 & 12.0 & 11.4 \\
\hline " & " & 1.5 & 5.6 & 5.6 & 5.6 \\
\hline
\end{tabular}

液体学用い，粘性降下剂主同時使用している。乙の表 より次の結論萑得る。(1) $\mathrm{Ca}(\mathrm{OH})_{2}$ と $\mathrm{NaOH}$ の增

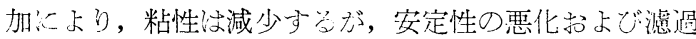
水の增加上交る。（2）CMCD混合は滤過水炽娍少さ

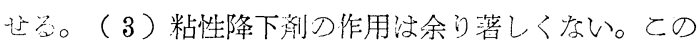
なかでンミン酸统比较的付效に作用する。

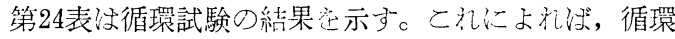
中汇粘性が変化し，不交定な状態汇なつている。

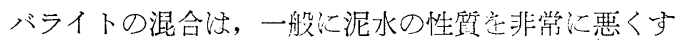

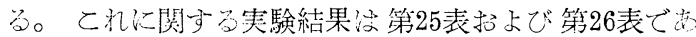
る。実験方法としては，比宒 1.011 のベントナイト液に 対し $\mathrm{Ca}(\mathrm{OH})_{2}, \mathrm{NaOH}$ 招々じ $\mathrm{CMC}$ 在混合し粘性学測 定する。次にこれに $50 \%$ (望畒百分率) のバライト在混 合して粘性灻测定与る。さらにバライト辛混合し， 100

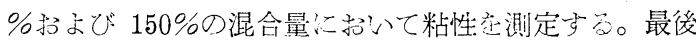

第 23 表 水酸化カルシウム扎よび苛性ソーダの作用（温度 $24 \sim 27^{\circ} \mathrm{C}$ )

\begin{tabular}{|c|c|c|c|c|c|c|c|c|c|c|c|c|c|c|c|}
\hline \multirow{2}{*}{$\begin{array}{c}\text { 混 } \\
\mathrm{Ca} \\
\left(\begin{array}{c}\mathrm{OH} \\
\%\end{array}\right)_{2} \\
\end{array}$} & \multicolumn{2}{|c|}{ 合＼cjkstart薬＼cjkstart品 } & \multirow{2}{*}{$\begin{array}{l}\text { 粘 性 降下 } \\
\text { 竓 の 種 類 }\end{array}$} & \multicolumn{5}{|c|}{ 粘性降下刘の混合による粘性* } & \multirow{2}{*}{\begin{tabular}{|l}
24 時間 \\
後の粘 \\
性* \\
c.p.
\end{tabular}} & \multirow{2}{*}{\begin{tabular}{|c|}
24 時間 \\
後の水 \\
の分離 \\
$\%$
\end{tabular}} & \multirow{2}{*}{$\begin{array}{c}\text { 濾 } \\
1 \text { 分 } \\
\mathrm{cc}\end{array}$} & \multicolumn{2}{|c|}{ 過 試 験 } & \multicolumn{2}{|c|}{$\begin{array}{l}\text { アルカ } \\
\text { り 度 }\end{array}$} \\
\hline & $\underset{\%}{\mathrm{NaOH}}$ & $\underset{\%}{\mathrm{CMC}}$ & & $\begin{array}{l}0 \% \\
\text { c.p. }\end{array}$ & $\begin{array}{l}1 \% \\
\text { c.p. }\end{array}$ & $\begin{array}{l}3 \% \\
\text { c.p. }\end{array}$ & $\begin{array}{l}5 \% \\
\text { c.p. }\end{array}$ & 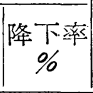 & & & & $\begin{array}{c}30 \text { 分 } \\
\mathrm{cc}\end{array}$ & $\begin{array}{l}\text { 泥壁 } \\
\mathrm{mm}\end{array}$ & $\begin{array}{l}P \\
c c\end{array}$ & $\begin{array}{l}\mathrm{M} \\
\mathrm{cc}\end{array}$ \\
\hline - & 一 & - & - & - & 一 & - & 一 & - & - & 0 & 3.5 & 20.0 & 0.5 & - & 一 \\
\hline - & - & 0.3 & 水 & 440 & 400 & 350 & 290 & 66 & 330 & 0 & 1.5 & 11.0 & 0.5 & - & - \\
\hline - & - & " & フミン酸溶液 & 440 & 390 & 350 & 340 & 77 & 300 & 0 & 2.5 & 12.0 & 0.5 & - & 一 \\
\hline 一 & - & " & $\begin{array}{l}\text { タンニン } 0.3 \\
\text { \%溶液 }\end{array}$ & 440 & 350 & 290 & 240 & 55 & 120 & 0 & 2.0 & 12.5 & 0.5 & - & - \\
\hline 0.2 & 0.2 & - & 水 & 1100 & 1000 & 970 & 930 & 84 & 1200 & 1 & 6.0 & 35.0 & 1.5 & 1.6 & 2.5 \\
\hline " & " & - & フミン酸溶液 & 1300 & 450 & 40 & 6 & 0.5 & 5 & 2 & 10.0 & 32.5 & 1.0 & - & - \\
\hline " & " & - & $\begin{array}{l}\text { タン゙二ン } 0.3 \\
\text { \%溶液 }\end{array}$ & 1100 & 960 & 810 & 660 & 60 & 1400 & 1 & 10.0 & 46.0 & 2.0 & 1.9 & 2.5 \\
\hline " & " & - & \begin{tabular}{|l|} 
四燐酸ソーダ \\
$1 \%$ 溶液
\end{tabular} & 1300 & 1100 & 890 & 710 & 55 & 1300 & 2 & 7.5 & 44.0 & 2.0 & 2.0 & 2.5 \\
\hline 0.2 & 0.2 & 0.3 & 水 & 180 & 160 & 130 & 100 & 55 & 85 & 3 & 2.5 & 13.5 & 0.5 & - & - \\
\hline " & " & " & フミン酸溶液 & 180 & 77 & 88 & 57 & 32 & 21 & 3 & 4.0 & 15.5 & 0.5 & - & - \\
\hline " & " & " & $\mid \begin{array}{l}\text { タンニン } \\
\text { \%溶液 }\end{array}$ & 180 & 150 & 120 & 88 & 49 & 32 & 0 & 2.5 & 12.5 & 0.5 & - & - \\
\hline " & " & " & $\begin{array}{l}\text { 四燐酸ソーダ } \\
1 \% \text { 溶液 }\end{array}$ & 90 & 60 & 46 & 33 & 37 & 15 & 2 & 2.0 & 13.5 & 0.5 & 2.0 & 2.6 \\
\hline " & " & 0.5 & A 10 intil & 170 & 130 & 100 & 68 & 40 & 49 & 1 & 3.5 & 12.5 & 0.5 & 2.0 & 2.5 \\
\hline 1.0 & 1.0 & 0.3 & 水 & 75 & 50 & 43 & 41 & 55 & 22 & 19 & 5.0 & 22.5 & 1.0 & - & - \\
\hline$"$ & " & " & フミン酸溶液 & 75 & 38 & 21 & 16 & 21 & 11 & 3 & 4.5 & 20.0 & 1.0 & - & - \\
\hline " & " & " & $\begin{array}{l}\text { タンニン } 0.3 \\
\text { \%溶液 }\end{array}$ & 75 & 60 & 43 & 36 & 48 & 17 & 21 & 7.0 & 26.5 & 1.5 & 一 & - \\
\hline " & " & " & タンニン1\% & 75 & 54 & - & 45 & 60 & 12 & 2 & 5.0 & 20.0 & 1.5 & - & - \\
\hline " & " & " & $\begin{array}{l}\text { 四燐酸ソーダ } \\
1 \% \text { 溶液 } \\
\end{array}$ & 90 & 63 & 49 & 40 & 44 & 12 & 3 & 4.5 & 23.0 & 1.0 & 9.4 & 一 \\
\hline 1.0 & 1.0 & 0.5 & 水 & 77 & 68 & 67 & 45 & 58 & 21 & 2 & .5 & 7.0 & .5 & - & - \\
\hline " & " & " & フミン酸溶液 & 77 & 24 & 21 & 28 & 36 & 25 & 3 & 2.0 & 11.0 & 1.0 & 一 & - \\
\hline " & " & " & $\begin{array}{l}\text { タンニン } 0.3 \\
\text { \%溶液 }\end{array}$ & 77 & 60 & 46 & 64 & 83 & 24 & 3 & 4.5 & 17.5 & 1.5 & - & - \\
\hline " & " & " & $\begin{array}{l}\text { タンニン } 1 \% \\
\text { 溶夜 }\end{array}$ & 77 & 100 & 150 & 150 & 195 & 39 & 2 & 2.5 & 11.5 & 1.5 & - & - \\
\hline " & " & " & \begin{tabular}{|l|} 
四燐酸ソーダ \\
$1 \%$ 溶液
\end{tabular} & 110 & 64 & 58 & 26 & 24 & 18 & 2 & 3.5 & 16.0 & 1.0 & 9.1 & 10.1 \\
\hline
\end{tabular}

* 分散状態 
の5\%混合されたものを24時閒放置し, 再び粘性を測定 する。その後, 滤過試験を行引。泥水の比重况, バライ トの $50 \%$ の混合の場合は $1.34 ， 100 \%$ の混合の場合は 1.63，150\%の混合の場合注1.83とする。粘性降下剂と して第25表はフミン酸を使用し, 第26表注:タンニンを使 用した。第25表の実験結果法次のとと意味する。（1） バライトの混合は泥水の安定性学非常に悪くする（この ことは第23表と比較するととにより得られる）。（2） $\mathrm{Ca}(\mathrm{OH})_{2}$ 抬よで $\mathrm{NaOH}$ の濃度の増加心より 粘性は 隇少するが，濾過水经增加与る（3）CMCD混合に より滤過水が減少し, 特以安定性の堌加が落しい。(4) $\mathrm{NaOH}$ に対し $\mathrm{Ca}(\mathrm{OH})_{2}$ が多い場合には, 泥水の性質

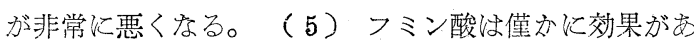
る。次に，第26表の実験結果では第25表と同!゙ょうなと そがいえるが，タンニンの効果が小さいととが目立つ。

\section{XI. 結 論}

以上には泥水の化学的処理に関する種々の実験結果学 示した。とのょうな実験結果学，現場の泥水処理に対し て応用することが, 掘さくを目的通りに進めるために, 必要となる。この研究の結論として, てれ関して次に 記す。

（1）泥水つ種々の物理的性質のうち, 比重・粘性・
第 24 表 循環試験

\begin{tabular}{|c|c|c|c|c|c|c|}
\hline ベントナノ & F $\mathrm{g}$ & $100 \mathrm{cc}$ & 5 & & & 1.0 \\
\hline $\mathrm{Ca}(\mathrm{OH})_{2}$ & & $\%$ & & & & 1.0 \\
\hline $\mathrm{NaOH}$ & & $\%$ & & & & 1.0 \\
\hline $\mathrm{CMC}$ & & $\%$ & & & & 0.3 \\
\hline 経 過 & 時 1 & & $\begin{array}{l}\text { 粘性 } \\
\text { c.p. }\end{array}$ & $\begin{array}{l}\text { 温度 } \\
{ }^{\circ} \mathrm{C}\end{array}$ & $\begin{array}{l}\text { 粘性 } \\
\text { c.p. }\end{array}$ & $\begin{array}{l}\text { 温度 } \\
{ }^{\circ} \mathrm{C}\end{array}$ \\
\hline & & & 93 & 23 & 160 & $25 \sim 30$ \\
\hline & .5 & & 23 & 24 & 53 & \\
\hline & & & 18 & 25 & 39 & \\
\hline & & & 15 & 26 & 41 & \\
\hline & & & 17 & 27 & 56 & \\
\hline & & & 15 & 28 & 93 & \\
\hline 16時閣 & 経過㷋 & & 40 & 22 & 380 & \\
\hline & & & $(440)$ & $"$ & (236) & \\
\hline & & & 1000 & 24 & 140 & \\
\hline & & & 500 & 26 & 880 & \\
\hline & 1 分 & $\mathrm{cc}$ & & & & .0 \\
\hline 濾過試 験 & 30 分 & $\mathrm{cc}$ & 10 & & & .5 \\
\hline & 泥壁 & $\mathrm{mm}$ & & & & .0 \\
\hline & $\mathrm{P}$ & $\mathrm{cc}$ & & & 11 & .2 \\
\hline アルカリ草 & M & $\mathrm{cc}$ & & & & .2 \\
\hline
\end{tabular}

※結含状態たビし（）は分散状態

第 25 表 バライト混合石灰泥水の性質一その 1 (温度 $20 \sim 24^{\circ} \mathrm{C}$ )

\begin{tabular}{|c|c|c|c|c|c|c|c|c|c|c|c|c|c|c|}
\hline 混 & 薬 & 品 & バラィ & の混 & 今によ & 万粘性* & & $\begin{array}{l}\text { 酸の } \\
\text { 粘性 }\end{array}$ & & $\begin{array}{l}\text { 24晆間 } \\
\text { 後の粘 }\end{array}$ & $\mid$\begin{tabular}{|l|}
24 晆間 \\
後の水
\end{tabular} & & 過 訌 & \\
\hline$\underset{\%}{\mathrm{Ca}(\mathrm{OH})_{2}}$ & $\underset{\%}{\mathrm{NaOH}}$ & $\begin{array}{c}\mathrm{CMC} \\
\%\end{array}$ & $\begin{array}{l}0 \% \\
\text { c.p. }\end{array}$ & $\begin{array}{l}50 \% \\
\text { c.p. }\end{array}$ & $\begin{array}{l}100 \% \\
\text { c.p. }\end{array}$ & $\begin{array}{c}150 \% \\
\text { c.p. }\end{array}$ & $\begin{array}{l}1 \% \\
\text { c.p. }\end{array}$ & $\begin{array}{l}3 \% \\
\text { c.p. }\end{array}$ & $\begin{array}{l}5 \% \\
\text { c.p. }\end{array}$ & $\begin{array}{l}\text { 性* } \\
\text { c.p. }\end{array}$ & $\begin{array}{c}0 \\
0 \text { 分離 } \\
\%\end{array}$ & $\begin{array}{l}1 \text { 分 } \\
\mathrm{cc}\end{array}$ & \begin{tabular}{|c|}
30 分 \\
$\mathrm{cc}$
\end{tabular} & $\begin{array}{l}\text { 泥壁 } \\
\mathrm{mm}\end{array}$ \\
\hline 0.2 & 0.2 & 0.1 & 57 & 290 & 440 & 630 & - & - & 175 & 72 & 34 & 4.0 & 17.5 & 11.0 \\
\hline I" & " & 0.3 & 28 & 100 & 260 & 490 & 290 & 210 & 210 & 120 & 3 & 4.5 & 18.5 & 5.5 \\
\hline " & " & 0.5 & 36 & 41 & 100 & 270 & 230 & 290 & 330 & 210 & 0 & 4.0 & 14.0 & 2.5 \\
\hline 1.0 & 1.0 & 0.1 & 12 & 200 & 390 & 520 & 240 & 120 & 80 & 30 & 34 & 12.0 & 67.5 & 21.5 \\
\hline$\therefore$ & " & 0.3 & 10 & 31 & 110 & 300 & 200 & 170 & 140 & 36 & 15 & 5.0 & 19.0 & 6.5 \\
\hline " & " & 0.5 & 26 & 36 & 120 & 220 & 200 & 190 & 170 & 62 & 2 & 5.0 & 17.5 & 8.5 \\
\hline 0.2 & 1.0 & 0.3 & 93 & 31 & 110 & 290 & 160 & 140 & 120 & 36 & 15 & 4.5 & 21.5 & โ2.0 \\
\hline 0.2 & 1.0 & 0.5 & 12 & 31 & 72 & 180 & 120 & 130 & 140 & 52 & 10 & 3.5 & 16.5 & 8.5 \\
\hline 1.0 & 0.2 & 0.5 & 190 & 340 & 790 & - & - & - & 850 & 370 & 17 & 17.0 & 81.5 & 30.5 \\
\hline
\end{tabular}

* 分散状態

滤過試験結果, 安定性が最も重要なものである。掘警中 の井戸に执いては，常にてれ関して測定する。泥水注 地下の状態の影響穻うけるので, 井戸ょり上つてきた泥 水の性質より, 地下の状態を判断する。次に地下の状態 に適するょうに泥水を処理して井戸のなか洖りてむ。

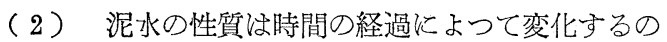
で, との点注意しながら, 泥水に対する薬品の作用な ぞを判断する必要がある。

（３）薬品の溶液中では乾燥ベントナイトの膨潤は
妨げられる。溶液の濃度が高い場合には、ベントナイト は全く膨閵せず，砂のょうになる。これは現場で乾燥心゙ ントナイトを扱う際に忘れてはならないことである。

（4）一般飞多燐酸ソーダおょびタンニン（ケーブ ラコ）泳泥水の粘性を下げるために有效である。しかし 種類によつて作用が少し異なるので，泥水適したもの 定選ぶ必要がある。

（5）泥水が食塩水の影響学受けると, その性質が 悪くなる。 $\mathrm{NaCl}$ の濃度が低い場合にのみ，乙の悪くな 
藤 井 清 光

第 26 表 バラィト混合石夷泥水の性質一その 2 (温度 $25 \sim 26^{\circ} \mathrm{C}$ )

\begin{tabular}{|c|c|c|c|c|c|c|c|c|c|c|c|c|}
\hline 混 & 合 薬 & 品 & $\begin{array}{l}\text { バラ } \\
\text { Kよ }\end{array}$ & $\begin{array}{l}\text { の混合 } \\
\text { 性* }\end{array}$ & $\begin{array}{l}\text { タン } \\
\text { 混合 }\end{array}$ & $\begin{array}{l}0.39 \\
\text { る 粘 }\end{array}$ & 液の & \begin{tabular}{|l|}
24 時間 \\
後の粘
\end{tabular} & {$\left[\begin{array}{l}24 \text { 時間 } \\
\text { 後の水 }\end{array}\right.$} & 濾 & 過 & 験 \\
\hline $\begin{array}{c}\mathrm{Ca}(\mathrm{OH})_{2} \\
\%\end{array}$ & $\begin{array}{c}\mathrm{NaOH} \\
\%\end{array}$ & $\begin{array}{c}\mathrm{CMC} \\
\%\end{array}$ & $\begin{array}{l}0 \% \\
\text { c.p. }\end{array}$ & $\begin{array}{c}150 \% \\
\text { c.p. }\end{array}$ & $\begin{array}{l}1 \% \\
\text { c.p. }\end{array}$ & $\begin{array}{l}3 \% \\
\text { c.p. }\end{array}$ & $\begin{array}{l}5 \% \\
\text { c.p. }\end{array}$ & $\mid \begin{array}{l}\text { c.p. } \\
\text { c.p. }\end{array}$ & $\begin{array}{c}\text { の分離 } \\
\%\end{array}$ & $\begin{array}{c}1 \text { 分 } \\
\mathrm{cc}\end{array}$ & $\begin{array}{c}30 \text { 分 } \\
\mathrm{cc}\end{array}$ & $\begin{array}{l}\text { 泥壁 } \\
\mathrm{mm}\end{array}$ \\
\hline 0.2 & 0.2 & 0.1 & 83 & 700 & 580 & 500 & 440 & 230 & 25 & 44.5 & 300.0 & 60.0 \\
\hline " & " & 0.3 & 29 & 300 & 190 & 170 & 150 & 72 & 15 & 6.0 & 39.5 & 11.5 \\
\hline "I & "I & 0.5 & 36 & 250 & 180 & 170 & 130 & 67 & 2 & 3.5 & 20.0 & 9.0 \\
\hline 1.0 & 1.0 & 0.1 & 41 & 600 & 500 & 380 & 320 & 230 & 18 & 15.0 & 92.5 & 26.5 \\
\hline " & " & 0.3 & 52 & 420 & 260 & 180 & 150 & 62 & 29 & 34.0 & 240.0 & 50.0 \\
\hline "I & " & 0.5 & 26 & 260 & 140 & 120 & 98 & 31 & 17 & 4.0 & 27.5 & 15.5 \\
\hline 0.2 & 1.0 & 0.3 & 9 & 144 & 98 & 83 & 62 & 41 & 21 & 16.0 & 78.0 & 23.0 \\
\hline 1.0 & 0.2 & " & 440 & 610 & 540 & 500 & 450 & 260 & 22 & 37.5 & 252.5 & 60.0 \\
\hline
\end{tabular}

* 分散状態

つた性質は薬品によつて改善される。

（6）界面活性剤は泥水の性質の改善に対しては, ごく弱い作用学示すのみである。

（7）泥水に石灰が加えられると，ごく僅かの量で あつても, 泥水の性質は非常に悪くなる。このととは温 度が高くなるこ，特に著しい。石死の混合量が少ない場 合には, この悪い作用はフミン酸溶液によつて改善され る。

（8）泥水に苛性ソーダが加えられるこ, 泥水の粘 性は増加する。苛性ソーダの混合量が少ない場合には, 一般の粘性降下剂は有效に作用する。

（9）石灰さ苛性ソーダが同時に泥水に加えられた 場合には，その混合比率务 1：1の時によい性質を示 す。高い温度では，この泥水の性質は悪くなる。

（10）石疢亡苛性ソーダが混合された泥水に, さら に溉粉尔たは C M C が加えられると, 泥水の性質は改善 される。
（11） バライトの混合は，一般に泥水の性質を非常 に覀くする。特に泥水の安定性が悪くなる。との悪い性 質を改善するには，CMCが非常に有効である。

この研究は東京大学工学部採油研究室に抬いて行われ たものである。実験の大部分は東京大学助手松本仙一氏 により行われ，一部ほ藤原幸雄氏（石油資源開発株式会 社）によつて行われた。と〉に嬮く感謝の意を表わす次 第である。

\section{文献}

1）藤井清光 : 粘土泥水の粘性及びイールドバリュー の基本的性質，石油技術協会誌，第 14 巻 2 号。

2）藤井清光: 逸水江関与る研究, 石油技術協会誌, 第17巻 4 号。

3）藤井清光：逸水に対する処理，石油技術協会誌， 第 22 巻 1 号。

4) 藤井清光：泥水に対する C M C の作用, 石油技術 協会誌，第 21 巻 3 号。 